\title{
Rubber Industry Wastewater Treatment Using Sand Filter, Bentonite and Hybrid Membrane (UF-RO)
}

\author{
Elsa Rama Lumban Gaol ${ }^{1}$, Subriyer Nasir ${ }^{2}$, Hermansyah $^{3}$, Agung Mataram ${ }^{4}$ \\ 1. Graduate Program Student, Chemical Engineering Magister Program, Universitas Sriwijaya, Indonesia \\ 2. Department of Chemical Engineering, Faculty of Engineering, Universitas Sriwijaya, Indonesia \\ ${ }^{3 .}$ Department of Chemistry, Faculty of Mathematics and Natural Sciences, Universitas Sriwijaya, Indonesia \\ ${ }^{4}$ Department of Mechanical Engineering, Faculty of Engineering, Universitas Sriwijaya, Indonesia \\ *Corresponding Author: subriyer@unsri.ac.id
}

Article history

\begin{tabular}{|c|c|c|c|}
\hline Received & Received in revised form & Accepted & Available online \\
\hline 14 February 2019 & 16 March 2019 & 28 March 2019 & 30 March 2019 \\
\hline
\end{tabular}

\begin{abstract}
The study aims to utilize the Hybrid Membrane Technology (UF-RO) in reducing turbidity, iron and zinc in the liquid waste of the rubber industry. The pre-treatment process used was filtration and adsorption. The filtration process used filter columns containing silica sand and activated carbon, while the adsorption process used an adsorbent column containing bentonite. After the pre-treatment process, it was continued with the application Hybrid Membrane (UF-RO). The variables of the study were operation time of 15 to 90 minutes and flow rates of 7 and $14 \mathrm{~L} / \mathrm{min}$. The results showed that the optimum removal percentage of iron and zinc in the Reverse Osmosis Membrane were $84.86 \%$ and $96.29 \%$ at the feed flow rate of $14 \mathrm{~L} / \mathrm{min}$. The optimum removal percentage turbidity of $99.70 \%$ was achieved at the feed flow rate of $7 \mathrm{~L} / \mathrm{min}$ in the Reverse Osmosis Membrane. Finally, rubber industry wastewater treatment using Hybrid Membrane (UF-RO) was able to reduce turbidity, iron and zinc content, and the results were accorded with the quality standards regarding Water Quality.
\end{abstract}

Keywords: bentonite, hybrid membrane, rubber industry, sand filter, wastewater.

\begin{abstract}
Abstrak (Indonesian): Penelitian ini bertujuan untuk mengaplikasikan Teknologi Membran Hibrid (UF-RO) dalam mereduksi kekeruhan, besi dan seng pada limbah cair industri karet. Proses pre-treatment yang digunakan yaitu filtrasi dan adsorpsi. Proses filtrasi yaitu menggunakan kolom filter yang berisikan pasir silika dan karbon aktif, sedangkan proses adsorpsi yaitu menggunakan kolom adsorbent yang berisikan bentonit. Setelah proses pretreatment maka dilanjutkan dengan penggunaan Membran Hibrid (UF-RO). Variabel penelitian yaitu waktu operasi 15 sampai 90 menit dan laju alir 7 dan 14 L/menit. Hasil penelitian menunjukkan persentase rejeksi optimum terhadap besi dan seng pada Membran Reverse Osmosis sebesar 84,86\% dan 96,29\% pada umpan laju alir 14 L/menit. Persentase removal optimum kekeruhan sebesar 99,70\% tercapai pada laju alir 7 L/menit di Membran Reverse Osmosis. Akhirnya, pengolahan limbah cair industri karet menggunakan Membran Hibrid (UF-RO) mampu mereduksi kekeruhan, kandungan besi dan seng dengan hasil yang sesuai standar baku mutu tentang Syarat dan Pengawasan Kualitas Air.
\end{abstract}

Kata Kunci: bentonit, industri karet, limbah cair, membran hibrid, sand filter.

\section{Introduction}

Indonesia has the largest rubber plantation land in the world with an area of 3,616,694 ha [1]. Rubber (Hevea brasiliensis) is one commodity that contributes to increasing foreign exchange. However, the liquid waste produced from the rubber industry also has a negative impact on the environment and humans, if the waste is not a processed.

Rubber Liquid waste does not only contain high organic material only, but it contains high suspended solids, high nitrogen pollutants ( $\mathrm{N}$-organic, $\mathrm{N}-\mathrm{NH}_{3}$ ), high acidity and strong odor [2]. In addition, other components include suspended solids (in the remaining latex), organic matter (sugar, protein, lipids, etc. in the remaining latex), nitrogen and other pollutants (sulfates, heavy metals such as Iron and Zinc). [3]

The treatment of industrial wastewater containing heavy metal is very important. Heavy metals have toxicity and negative impacts on the environment. One process to eliminate heavy metal content from wastewater is conventional processing, such as chemical precipitation, ion exchange, electrochemical removal, chemical adsorption, physical adsorption, flocculation, and biological growth. The process has significant disadvantages, such as high energy, incomplete disposal and production of toxic sludge [4].

Membrane separation processes are often used to process inorganic wastes because it's simple operation. Membrane filtration is capable of treating inorganic waste, removing solid, suspended organic compounds and inorganic contaminants such as heavy metals. 
Membrane technology has been used in metal separation by Ultrafiltration, Nanofiltration and Reverse Osmosis [5].

Several studies for the treatment of waste from glove factories using flat-sheet Ultrafiltration Polyethersulfone (PES) membranes and operated in cross flow filtration with molecular weight cut-off (MWCO) $100 \mathrm{kDa}$ and $10 \mathrm{kDa}$ to evaluate the efficiency of rejection of certain parameters of wastewater. Membrane operates at 1.0 bar for inlet pressure and 0.2 bar for outlet pressure. The parameters used were chemical oxygen demand (COD), total suspended solids (TSS), ammonia nitrogen (AN), total Kjeddahl nitrogen (TKN), turbidity, $\mathrm{pH}$, color and metals content. In addition, analyze of COD were carried out for dead-end filter paper filtration for comparison. The best final results from cross-flow filtration of $10 \mathrm{kDa}$ membranes, where the highest percentage of removal was achieved for COD $(73.07 \%)$, TSS $(90.61 \%)$ and turbidity (90.60), respectively. In addition, it shows that the resulting permeate safely discharged into the water stream in accordance with the requirements of Malaysian environmental laws and regulations [6].

The removal of $\mathrm{Cu}$ (II) and $\mathrm{Zn}$ (II) ions from synthetic wastewater using Chitosan-enhanced membrane filtration was studied. The result showed Chitosan can significantly enhanced metals removal by 6-10 times compared to the using a stand-alone membrane. Parameters such as $\mathrm{pH}$, ligand concentration, pressure and membrane pore size were found to significant effect on metal ion rejection rates. A major disadvantage of using ultrafiltration membranes is that the operational costs are higher due to membrane fouling [7].

Recently, UF has an efficient pre-treatment for reverse osmosis (RO) systems [8]. One important to evaluate the costs and benefits of UF operations as pretreatment, especially for high sources of decayed feed water such as surface water, wastewater or open intake sea water [9]. Integrated Membrane System (IMS) is a system that has been designed with MF / UF membrane systems as maintenance before RO systems [10, 11]. Based on the statement above that pre-treatment of process water before $\mathrm{RO}$ is very important for membrane life and the economical operation of Reverse Osmosis Membrane [12].

As a pretreatment process, silica sand and activated carbon will be used as a sand and bentonite as an adsorbent. The use of using sand filters aims to reduce the suspended solids content, and increase the percentage of turbidity rejection in the rubber industry wastewater. Bentonite is the most abundant argillaceous material that can be used in wastewater treatment. They are reported as an efficient and inexpensive adsorbent for some heavy metals (Copper, tin, cadmium, zinc, and iron) while modifying bentonite is used to remove ${ }^{60} \mathrm{Co}$ radionuclides from radioactive waste solutions. Great adsorption ability due to major mineral components such as montmorillonite, smectite and clay [13].

Electrocoagulation efficiency as a turbidity removal process has been studied using bentonite as a source of turbidity. The impact of operational parameters such as current input, contact time, electrolyte concentration, and initial turbidity on the efficiency of coagulation was studied. This process was found to achieve turbidity removal. The results of the study shown the low residual turbidity was 0.5 and 0.75 NTU for samples with initial turbidity of 112 and 52 NTU, respectively [14].

The current research combines the pretreatment process using sand filter, bentonite and Hybrid Membrane (UF-RO) in reducing the turbidity and content of Iron and Zinc in the liquid waste of the rubber industry. Even though Iron, Zinc, and turbidity are not regulated in the quality standards of rubber wastewater, the content is regulated in Minister Of Health No. 416/MEN.KES/PER/IX/1990 concerning quality standards regarding Water Quality Requirements And Supervision [15].

\section{Experimental Section}

\subsection{Materials}

The rubber industry liquid waste from a rubber factories at Gandus, Palembang, South Sumatra, Indonesia was used as the sample in the experiment. The sand filter column contains $15 \mathrm{~kg}$ of silica sand and contains $15 \mathrm{~kg}$ of activated carbon. The adsorbent column contains $25 \mathrm{~kg}$ of bentonite, which activated using $1.2 \mathrm{M} \mathrm{H}_{2} \mathrm{SO}_{4}$ solution. Sand filter column equipped with three cartridge filte with pore diameter $0.5 \mu \mathrm{m} ; 0.3$ $\mu \mathrm{m}$; and $0.1 \mu \mathrm{m}$, while the adsorbent column is equipped a cartridge filter with pore diameter $0.1 \mu \mathrm{m}$. The main equipment to treat the adsorbent product using Hybrid Membrane (Ultrafiltrasi-Reverse Osmosis) with specification of Ultrafiltration Membrane; type HM 90 UF, shell material stainless steel, model external force (outside-in filtration) and module size $\phi$ 90x1230 mm.

\subsection{Bentonite Characterization}

Bentonite used is bentonite powder with a particle size of 60 mesh ( 250 micron). Then the activation of bentonite was done by washing and soaking with distilled water and chemicals using $1.2 \mathrm{M}$ sulfuric acid $\left(\mathrm{H}_{2} \mathrm{SO}_{4}\right)$ and drying with an oven at $110^{\circ} \mathrm{C}$.

\subsection{Procedures}

Samples was pumped into the sand filter column with a feed flow rate of $5 \mathrm{~L} / \mathrm{min}$ and proceed to cartridge filters. The next process is using the adsorbent column with a feed flow rate of $5 \mathrm{~L} / \mathrm{min}$ and proceed to a cartridge filter. After that, the output of the previous process was collected in the reservoir tank ultrafiltration membrane. The Ultrafiltration Membrane can be operated with varying feed flow rates 7 and $14 \mathrm{~L} / \mathrm{min}$. The output of the Ultrafiltration Membrane is collected 
in the Reverse Osmosis Membrane tank. The Reverse Osmosis Membrane can be operated with varying feed flow rates 7 and $14 \mathrm{~L} / \mathrm{min}$, and the permeate was collected in the final reservoir tank. Experimental set-up is shown in Figure 1.

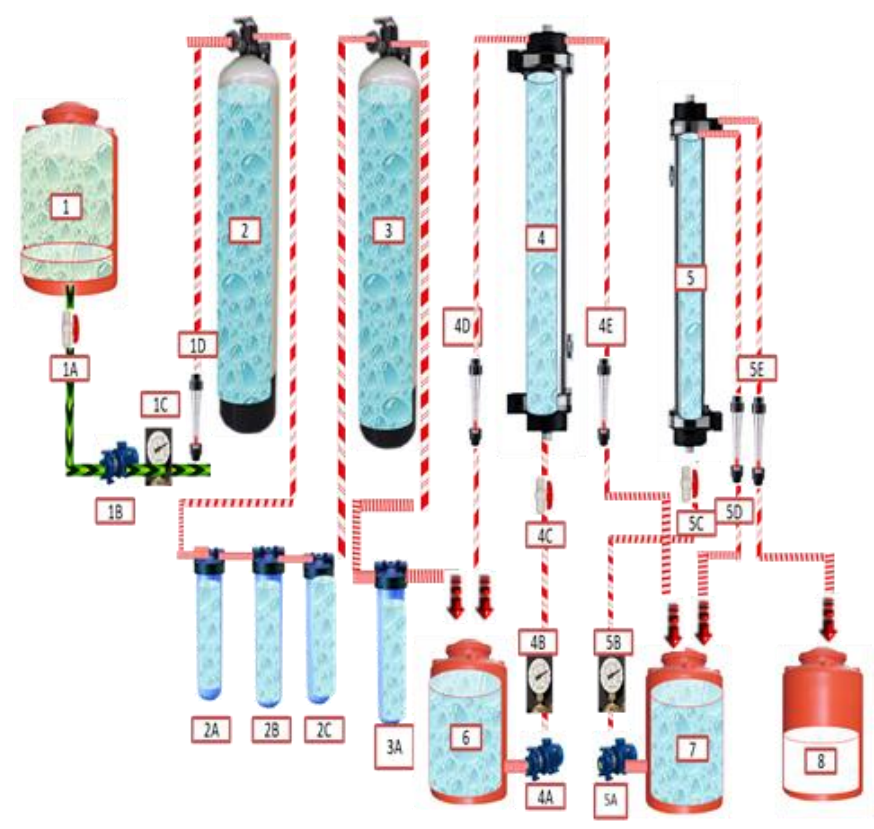

Figure 1. Experimental Set-Up

(1. Waste Storage Tank; 1a. Valve; 1b. Pump; 1c. Pressure Gauge; 1d. Flowmeter; 2. Sand Filter Column; 2a. Cartridge filter (size $0.5 \mu \mathrm{m}) ; 2 \mathrm{~b}$. Cartridge filter (size $0.3 \mu \mathrm{m}) ; 2 \mathrm{c}$. Cartridge filter (size $0.1 \mu \mathrm{m}) ; 3$. Bentonite Adsorbent Column; 3a. Cartridge filter (size $0.1 \mu \mathrm{m}) ; 4$. Ultrafiltration Membrane; 4a. Pump; 4b. Pressure Gauge; 4c. Valve; 4d. Inlet Flowmeter; 4e. Outlet Flowmeter; 5. Ultrafiltration Membrane; 5a. Pump; 5b. Pressure Gauge; 5c. Valve; 5d. Inlet Flowmeter; 5e. Outlet Flowmeter; 6. Ultrafiltration Membrane Storage Tank; 7. Reverse Osmosis Membrane Storage Tank; 8. Permeate Tank)

\subsection{Analysis Data}

The samples were taken periodically at $15,30,45$, 60, 90 minutes and feed flow rate of 7 and $14 \mathrm{~L} / \mathrm{min}$ for analysis turbidity, and samples were only taken at 90 minutes to analyze Iron and Zinc concentration with feed flow rates of 7 and $14 \mathrm{~L} / \mathrm{min}$. To analyze turbidity using Turbidity meter (type: Thermo Scientific, merk: EUTECH TN-100) and for determining iron and zinc content using Indonesian National Standard 06-6989.42004 and 06-6989.7-2009.

\section{Results and Discussion}

The results analysis of the initial liquid waste of the rubber industry is shown in Table 1.
Table 1.Initial Liquid Waste Of The Rubber Industry

\begin{tabular}{cccc}
\hline No. & Parameter & Unit & Value \\
\hline 1. & $\mathrm{Fe}$ & $\mathrm{mg} / \mathrm{L}$ & 0.317 \\
2. & $\mathrm{Zn}$ & $\mathrm{mg} / \mathrm{L}$ & 0.027 \\
3. & Turbidity & NTU & 268 \\
\hline
\end{tabular}

3.1. Effect of Pretreatment and Hybrid Membrane (UF$R O)$ in Decreasing Iron Concentration

The results of the initial iron analysis on rubber wastewater were $0.317 \mathrm{mg} / \mathrm{L}$, while the quality standard was $0.3 \mathrm{mg} / \mathrm{L}$. Effect of Pretreatment and Hybrid Membrane (UF-RO) in decreasing Iron concentration is shown in Figure 2.

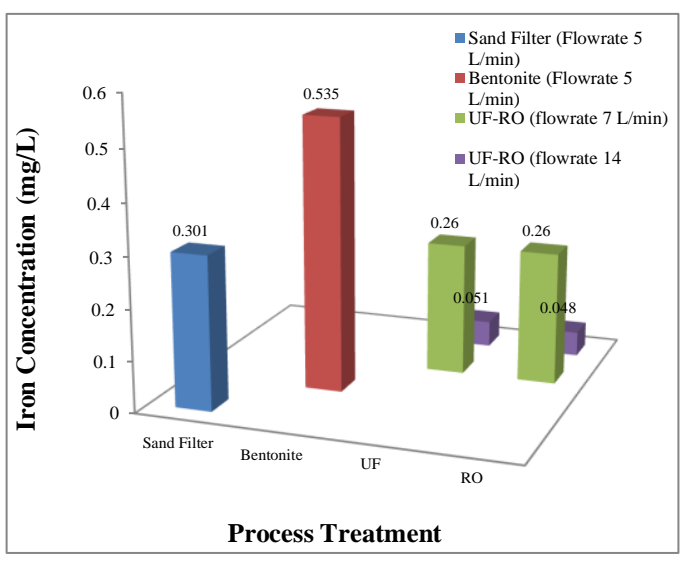

Figure 2. Effect of Pretreatment and Hybrid Membrane (UF-RO) in Decreasing Iron (Fe)

Figure 2. Shows a decrease in iron concentration. The use of the sand filter column showed the lowest iron concentration of $0.098 \mathrm{mg} / \mathrm{L}$. Continued with the use of bentonite adsorbent column showed the lowest iron concentration of $0.061 \mathrm{mg} / \mathrm{L}$. This indicated that the addiction of the adsorption process using bentonite resulted in greater iron removal. Furthermore, at variations in feed flow rates 7 and $14 \mathrm{~L} / \mathrm{min}$ in Hybrid membranes (UF-RO), it was shown that the feed flow rate of $14 \mathrm{~L} / \mathrm{min}$ was most optimum in decreasing iron content. The Ultrafiltration membrane with a feed flow rate of $14 \mathrm{~L} / \mathrm{min}$ showed an iron concentration of 0.051 $\mathrm{mg} / \mathrm{L}$ and in Reverse Osmosis membrane with a feed flow rate of $14 \mathrm{~L} / \mathrm{min}$, indicating an iron concentration of $0.048 \mathrm{mg} / \mathrm{L}$ or a removal percentage of $84,86 \%$ and the results obtained that iron concentration is accordance with the Indonesian National Standard (SNI).

\subsection{Effect of Pretreatment and Hybrid Membrane (UF- $R O)$ in Decreasing Zinc Concentration}

One of the heavy metals with high toxicity is5 zinc. In rubber wastewater research was carried out to determine the levels of metals including zinc from industrial rubber wastewater. Zinc is a fairly reactive metal that reacts with oxygen and dilute acid to release 
hydrogen. The impact of industrial wastewater is increasing the amount of zinc in water and triggering health and environmental problems. In general, zinc concentrations increase due to human activity and can occur naturally in air, water, and soil. The results of the initial analysis for zinc concentration in rubber wastewater were $0.027 \mathrm{mg} / \mathrm{L}$. Effect of pretreatment and Hybrid Membrane (UF-RO) in decreasing zinc is shown in Figure 3.

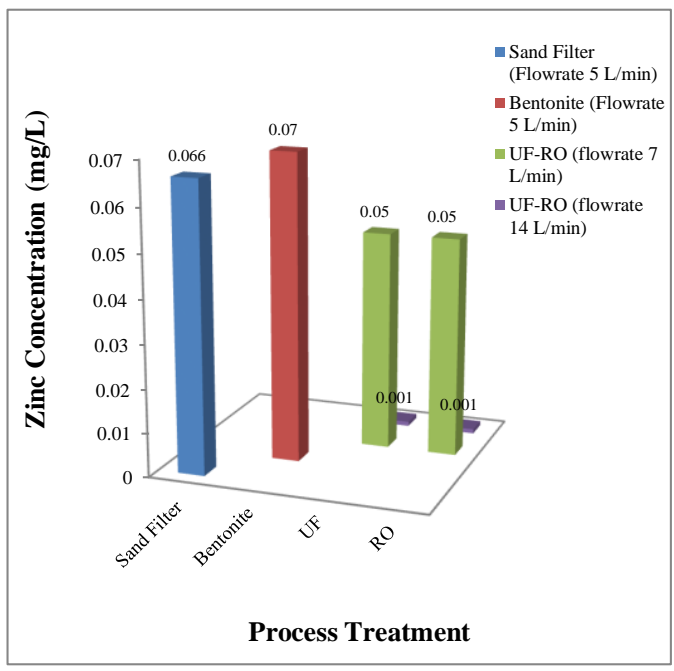

Figure 3. Effect of Pretreatment and Hybrid Membrane (UF-RO) in Decreasing Zinc

Figure 3. Shows a decrease in zinc content. The use of the sand filter column showed the lowest zinc concentration of $0.003 \mathrm{mg} / \mathrm{L}$. Continued with the use of bentonite adsorbent column showed the lowest zinc value of $0.001 \mathrm{mg} / \mathrm{L}$. This indicated that the adsorption process using bentonite resulted in greater iron removal. Furthermore, at variations in feed flow rates 7 and 14 $\mathrm{L} / \mathrm{min}$ in Hybrid membranes (UF-RO), it was shown that the flow rate of $14 \mathrm{~L} / \mathrm{min}$ was most optimum in decreasing zinc content. The Ultrafiltration membrane with a feed flow rate of $14 \mathrm{~L} / \mathrm{min}$ showed a zinc concentration of $0.001 \mathrm{mg} / \mathrm{L}$ and in Reverse Osmosis membrane with a feed flow rate of $14 \mathrm{~L} / \mathrm{min}$, indicating a zinc concentration of $0.001 \mathrm{mg} / \mathrm{L}$ or a removal percentage of $96,29 \%$ And the results obtained that zinc concentration is accordance with the Indonesian National Standard (SNI).

\subsection{Effect of Pretreatment and Hybrid Membrane (UF- $R O)$ in Decreasing Turbidity}

Determination of wastewater quality based on the amount of colloid and suspended material was carried out by turbidity measurement [14]. The results of the initial analysis for turbidity in rubber wastewater were
268 NTU. Effect of pretreatment and Hybrid Membrane (UF-RO) VS turbidity is shown in Figure 4.

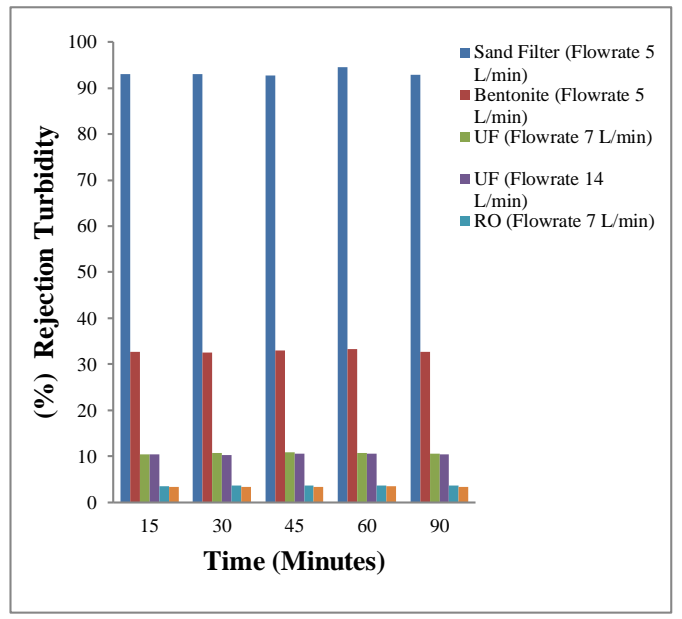

Figure 4. Effect of Pretreatment and Hybrid Membrane (UF-RO) VSTurbidity

Figure 4. Shows that the use of sand filters can reduce turbidity ranging from $92.95-94.49 \%$ at an operating time of 15 to 90 minutes. Then in the adsorption process with bentonite showed the percentage reduction of turbidity ranged from 32.51$33.35 \%$. There is no large difference in turbidity removal percentage with time variation in the sand filter and bentonite. The pretreatment process aims to improve membrane performance and prevent fouling and scaling on the membrane. Furthermore, the variation in the feed flow rate and time in the Hybrid Membrane (UF-RO) shows a fluctuating result with the turbidity removal percentage.

In Ultrafiltration membrane with a feed flow rate of $7 \mathrm{~L} / \mathrm{min}$ the percentage removal of turbidity ranges from $10.39-10.86 \%$, and at the feed flow rate of 14 $\mathrm{L} / \mathrm{min}$ the percentage removal of turbidity ranges from 10.29-10.63\%. The Reverse Osmosis Membrane with a feed flow rate of $7 \mathrm{~L} / \mathrm{min}$ the removal percentage of turbidity ranged from 3.48-3.69\%, and the removal percentage of turbidity with a feed flow rate of 14 $\mathrm{L} /$ min ranged from $3.38-3.51 \%$. The results showed that at a lower feed flow rate the removal rate obtained was higher, while the best percentage removal of turbidity using Reverse Osmosis membrane was $99.70 \%$ in 90 minutes operation time and the results obtained that turbidity is accordance with Indonesian National Standard (SNI)

\section{Conclusion}

The percentage of removal obtained using sand filters, bentonite and Hybrid Membranes (UF-RO) for Iron and Zinc was $84.86 \%$ and $96.29 \%$ at a feed flow 
rate of $14 \mathrm{~L} / \mathrm{min}$, and the removal percentage of turbidity was $99.70 \%$ at the feed flow rate $7 \mathrm{~L} / \mathrm{min}$. In addition, the reduction of turbidity, iron and zinc used sand filters, bentonite and Hybrid Membrane (UF-RO) are in accordance with the Indonesian National Standard (SNI).

\section{Acknowledgement}

Thank you to my supervisor Prof. Ir. Subriyer Nasir, MS., Ph.D and Hermansyah, S.Si., M.Si., Ph.D for guidance in completing this research. Thanks also to $\mathrm{Mr}$. Subahan as an analyst at the Laboratory of Separation and Purification which was the place where the research was conducted.

\section{References}

[1] Direktorat Jendral Perkebunan. 2014. Luas Areal, Produksi, dan Produktivitas Perkebunan di Indonesia.

[2] Nguyen, T. V. 1999. Sustainable Treatment Of Rubber Latex Processing Wastewater: The UASB-System Combined With Aerobic PostTreatment PhD Thesis Wageningen University, Netherland.

[3] Nguyen, N. H., and Luong, Thao, T. 2012. Situation Of Wastewater Treatment Of Natural Rubber Latex Processing In The Southeastern Region, Vietnam. Journal of Vietnamese Environment. Vol. 2, No. 2, pp. 58-64.

[4] Barakat, A.M. 2010. New Trends In Removing Heavy Metals From Industrial Wastewater. Arabian Journal of Chemistry.Vol. 4, Issues 4, pp. $361-377$.

[5] Maximous, N.N., Nakha, F.G. and Wan, W. K. 2010. Removal Of Heavy Metal From Waste Water By Adsorption And Membrane Processes: A Comparative Study. World Academy of Science, Engineering and Technology, International Journal of Environmental And Ecological Engineering. Vol. 4, No. 4.

[6] Yap, A.S., Ibrahim, S. and Ang, K.B. 2013. Treatment of Rubber Glove Wastewater by
Ultrafiltration. Malaysian Journal of Science. 32(1); pp. 61-65

[7] Juang, R.S., and Shiau, R.C. 2000. Metal Removal From Aqueous Solutions Using Chitosan-Enhanced Membrane Filtration. Journal Of Membrane Science. Vol. 165, Issue 2, pp. 159-167.

[8] Clever, M., Jordt, F., Knauf, R., Rabiger, N., Rudebusch, M., and Hilter-Scheibel, R. 2000. Process Water Production from River Water by Ultrafiltration and Reverse Osmosis. Desalination. Vol. 131, Issues 1-3, pp.325-336.

[9] Bates, W.T. Capillary UF as RO pretreatment. www.membranes.com

[10] Nederlof, M.M., Kruithof, J.C., Taylor, J.S., Kooij, D.v.d., and Schippers, J.C. 2000. Comparison Of NF/RO Membrane Performance In Integrated Membrane Systems. Desalination. Vol. 131, pp.257-269.

[11] AWWA, Lyonnaise des Eaux Water Research Commission of South Africa (1996). Water Treatment Membrane Processes. New York, McGraw-Hill, Inc.

[12] Ding, S., Shen, J., Xu, B., Liu, Q., and Sun, Y. 2011. The Factors On Removal Of Zink Cation From Aqueous Solution By Bentonite. Journal Of Natural Resources. Vol. 2, pp. 107-113.

[13] Abizaid, N.S., Bukhari, A.A., and Al-Hamouz, Z.M. 2008. Removal of Bentonite Causing Turbidity by Electro-Coagulation. Journal of Environmental Science and Health, Part A. Vol. 33, Issue 7.

[14] Minister Of Health No. 416/MEN.KES/PER/IX/ 1990. Republik Indonesia.

[15] MetCalf and Eddy. 2003. Wastewater Engineering: Treatment, Disposal and Reuse, Edisi 4. New York: McGraw-Hill Book Company. 